\title{
Feeding frequencies and nest defence of Fieldfares in relation to body size, physical condition and sex of parents
}

\author{
Olav Hogstad
}

Hogstad, O. 2004. Feeding frequencies and nest defence of Fieldfares in relation to body size, physical condition and sex of parents. - Ornis Norvegica 27: 68-72.

\begin{abstract}
Nestling care is an energetic demanding period for most parents of altricial birds, and the parents relative contribution to nestling feeding rates may differ. The mean feeding rate of one-week old nestlings (number of nest visits per hour) by Fieldfare females was lower than that of males. The sexes did not differ in physical condition (based upon the amount of subcutaneous fat visible in the furculum or body-mass:wing-length ratio) in the nest building and egg-laying periods, but after hatching the females had decreased in body mass and physical condition whereas males did not. Males, but not females, increased their intensity of nest defence after hatching. Large males (based on wing length) had a higher feeding rate than smaller ones, whereas large females had not.
\end{abstract}

Olav Hogstad, Norwegian University of Science and Technology, Section of Natural History, NO-7491 Trondheim, Norway.E-mail: Olav.Hogstad@vm.ntnu.no

\section{INTRODUCTION}

Nestling care is a stressful and energetic demanding period for most parents of altricial birds. The parents relative contribution to nestling feeding rates may differ, depending on differences in ability to engage in parental care. The time and energy demands upon the parents may be related to the requirements of their young, but also to environmental factors affecting the adults.

In this paper, I present the results of a study of sexual differences in the nestling feeding rate by Fieldfares Turdus pilaris breeding in a mountain forest in central Norway. The females build the nest alone, incubate the eggs and brood the young, but both sexes feed the young. Since females spend much of their time at the nest when incubating and brooding the young, probably at the expense of their own bodily condition (e.g. Hogstad in press), I suggested that females should decrease in physical condition whereas males should not. Since I earlier have found a positive relationship between nest defence and the condition of the Fieldfares (Hogstad 1993), I also suggested that females should defend and feed their nestlings at a lower rate than males.

\section{METHODS}

Being part of a passerine community study started in 1966, the Fieldfare study was carried out in the breeding seasons of 1996-1998 in Budal $\left(c .63^{\circ} \mathrm{N}\right)$, central Norway, in a homogeneous 
subalpine heath birch forest consisting of Betula pubescens ssp.czerepanovii. The forest extends from 750 to $900 \mathrm{~m}$ asl, and the general tree height is 4-6 m. Fieldfares nest either solitarily or in small colonies (2-6 pairs). In the present study, only solitary Fieldfares nesting more than 100 $\mathrm{m}$ from the nest of the nearest neighbour have been studied.

Each year, four pairs (in total 12 pairs) were caught in mist nets during their nest-building and egg-laying periods. The birds were colour-ringed, sexed (on the basis of crown pattern, Svensson 1992), and their wing-lengths and body-mass were recorded. Their physical condition was estimated on the basis of 1) the ratio of bodymass to wing-length, and 2) from an index of the amount of subcutaneous fat deposition visible as fat in the furculum, recorded on a 5-degree scale: 0 , no fat; 1 , traces; 2 , half full; 3 , full; 4 , furculum overflowing (see Hogstad 1993). Later, some of these birds (4 females, 3 males) were recaptured when their nestlings were 2-5 days old, and their body mass and fat in the furculum were recorded.

The nest defence by the Fieldfares in their second week of incubation (clutch size 5-6) was estimated in the response to a human intruder (the author), considered to represent a simulation of the presence of a nest predator. I observed the response of the parents when I approached and stayed close to their nest tree for one minute. The experiment was repeated when the nestlings ( 5 or 6 per nest) were one week old. Hogstad (1991) and Meilvang et al. (1997) have tested the effects of multiple trials on Fieldfares and shown that their nest defence behaviour was not influenced by the number of repeated experiments during the breeding season. The defence reaction of the birds was recorded using the following predetermined scale: 1) leaving the nest area silently; 2) leaving the nest area silently, but making a few alarm calls whilst staying more than $40 \mathrm{~m}$ away from the nest; 3) leaving the nest area silently, but calling persistently whilst remaining $15-40 \mathrm{~m}$ from the nest; 4) calling persistently and remain- ing less than $15 \mathrm{~m}$ from the nest; 5) attacking the observer, frequently also by defecating.

The feeding rates of the adults were recorded by measuring the number of feeding visits during one hour between $10 \mathrm{~h}$ and $13 \mathrm{~h}$. In 1996, the feeding rates were recorded for two of the pairs when their nestlings were 12 days old. The observations were made from a hide about 15 $\mathrm{m}$ from the nest.

All tests are two-tailed, and were performed using SPSS 11.0. Means are presented \pm 1 SD.

\section{RESULTS}

\section{Size and physical condition}

The males were larger (males wing-length: mean $146.0 \pm 2.2 \mathrm{~mm}, \mathrm{n}=12$; females: $143.8 \pm 2.3 \mathrm{~mm}$, $\mathrm{n}=12$; Student $\mathrm{t}$-test, $\mathrm{t}_{22}=-2.42, \mathrm{p}=0.02$ ) and heavier than the females (in the nest-building and egg-laying periods: body-mass of males $115.3 \pm$ $2.0 \mathrm{~g}$; females $112.1 \pm 3.4 \mathrm{~g} ; \mathrm{t}_{22}=-2.81, \mathrm{p}=0.01$ ).

The sexes did not differ in physical condition in the nest building and egg-laying periods (fat index males: $1.2 \pm 0.8$; females: $0.9 \pm 0.8$; MannWhitney U-test, $\mathrm{z}=-0.66$, ns; body-mass: winglength ratio males: $0.79 \pm 0.01$; females: 0.78 $\left.\pm 0.02 ; \mathrm{t}_{22}=-1.38, \mathrm{~ns}\right)$. Fat index score increased with body size in males $\left(r_{s}=0.60, p=0.04\right)$, but not in females $\left(r_{s}=0.26, n s\right)$.

Four females recaptured just after hatching had decreased in body mass (from a mean of $112.0 \mathrm{~g}$ in the egg-laying period to $103.0 \mathrm{~g}$ ), subcutaneous fat content (from 1.5 to 0.0 ) and body-mass:winglength (from 0.78 to 0.71 ). In contrast, three males remained stable in body-mass (from $115.0 \mathrm{~g}$ to $114.0 \mathrm{~g}$ ), subcutaneous fat content (from 1.7 to 1.3) and body-mass:wing-length (from 0.79 to 0.78 ). Thus, as suggested, the mean body-mass of females was less $\left(\mathrm{t}_{5}=-4.47, \mathrm{p}=0.007\right)$, their fat index less $(\mathrm{z}=-2.37, \mathrm{p}=0.018)$ and their bodymass: wing-length ratio less $\left(\mathrm{t}_{5}=-3.99, \mathrm{p}=0.01\right)$ than that of males in the nestling period. 


\section{Feeding rates}

The feeding rate of females (mean number of nest visits per hour: $2.9 \pm 0.8$ ) when the nestlings were one week old was, as expected, lower than that of males $(3.8 \pm 0.8$, Mann-Whitney U-test, $\mathrm{z}=-2.35, \mathrm{p}=0.019)$. The number of nest visits by males correlated positively with their wing length $\left(r_{s}=0.70, p=0.011\right.$, Table 1$)$.

Each sex of one pair fed their 12-day-old nestlings 4 times/hour (the same as when their nestlings were one week old). For another pair, the rates were 4 times for the female ( 3 visits to one-week-old nestlings) and 6 times for the male (5 visits to one-week-old nestlings).

\section{Nest defence}

The nest defence against the human predator in the birds' second week of incubation varied from leaving the nest area silently (response 1) to calling persistently when remaining less than $15 \mathrm{~m}$ from the nest (response 4). No sexual difference was found in the mean nest defence (males 2.3 \pm 0.7 ; females $2.8 \pm 0.8, \mathrm{n}=12$; MannWhitney U-test, $\mathrm{z}=-1.68, \mathrm{p}=0.093$ ).

The intensity of nest defence by the same six males increased from a mean of 2.3 (before hatching) to $3.8 \pm 0.4$ after hatching $(\mathrm{z}=-2.42$, $\mathrm{p}=0.016$ ), while that of six females did not differ (from 3.0 before hatching to $3.5 \pm 0.5$ after hatching; $\mathrm{z}=-1.04$, ns).

\section{DISCUSSION}

The Fieldfare females decreased in body mass and physical condition between the periods of nest-building and egg-laying, and the period after hatching, whereas males did not. Since brooding and feeding are incompatible, brooding females have less time for feeding themselves than have males, and may therefore draw upon their body reserves (cf. Ricklefs \& Hussel 1984). I have earlier found that Fieldfare females exceeded their mates in nest defence before hatching, whereas males defended the nest more than females after hatching (Hogstad in press). The higher feeding rate of males when the nestlings were one week old points in the same direction. Males being the main food suppliers when the young are small is a pattern found also in other species (Biermann \& Sealy 1982, Johnson \& Best 1982). Thus, a weight loss and poorer condition after hatching may explain why females contributed less to the feeding of the young. Although anecdotal, the feeding rates maintained by two pairs of Fieldfares for their 12-day-old nestlings may indicate that the difference between the sexes persists until the young leave the nest. If this reflects a pattern where males and females increase their feeding rates equally, it is in accordance with that found for some species (e.g. Pinkowski 1978, Wittenberger 1982), but contrary to that reported for other species (Biermann \& Sealy 1982, Johnson $\&$ Best 1982). In a Swedish study of two Fieldfare pairs males maintained a constant contribution to feeding throughout the nestling period, whereas females increased their feeding rate as the nestlings grew older (Carlson \& Moreno 1986). The different results of the studies from Sweden and Budal, may be due to differences in the access to food. The Swedish study was made in a city park where earthworms, the predominant prey taken to the young, were always available due to the periodical watering of the lawns. In the Budal area, several Fieldfare pairs found their nestling food 1-2 km (and even more than $2 \mathrm{~km}$ ) away from the nest (e.g. Hogstad 1993). On the other hand, although females in my study area visited the nest less frequently than males, little is known of the sizes of the prey or loads delivered to their nestlings. Observations of feeding Fieldfares showed that males mainly delivered earthworms to their one-week-old nestlings, whereas females to a greater extent also delivered beetles and larvae of Epirrita autumnata (Hogstad unpublished data).

Nestling starvation is common in northern populations in the Fieldfare, and the nestling mortality may be high in some years (Wiklund 1983). The worm availability and travel costs between foraging areas and the nest probably affect, not solely 
Table 1. The relationships between feeding visits of one-week old nestlings (visits/hour) and size (wing-length, $\mathrm{mm}$ ), body mass ( $\mathrm{g}$ ), condition (amount of subcutaneous fat in the furculum, or body-mass:wing-length ratio) and nest defence (on 0-5 degree scale) by 12 Fieldfare pairs. $\left.*=p<0.05,{ }^{*}\right)=p<0.10$ in two-tailed Spearman correlation analysis.

\begin{tabular}{lllccc}
\hline Feeding visits & $\begin{array}{c}\text { Wing } \\
\text { length }\end{array}$ & $\begin{array}{l}\text { Body } \\
\text { mass }\end{array}$ & $\begin{array}{c}\text { Subcut. } \\
\text { fat }\end{array}$ & $\begin{array}{c}\text { Body-mass/ } \\
\text { wing-length }\end{array}$ & $\begin{array}{c}\text { Nest } \\
\text { defence }\end{array}$ \\
Males & $0.70^{*}$ & $0.51^{(*)}$ & 0.35 & 0.004 & -0.03 \\
Females & 0.24 & 0.40 & 0.28 & 0.17 & 0.20 \\
\hline
\end{tabular}

the nestling feeding rates and nestling mortality, but also the physical condition of the parents.

The return rate of adult Fieldfares to the breeding areas was lower in North Sweden than in SouthWest Sweden, and was related to a high proportion of young and inexperienced individuals in the northern population (Wiklund 1983). A low return rate of adult Fieldfares was also found in the Budal area (Hogstad unpubl. data), indicating a small number of old birds. As large males had a higher feeding rate than smaller males $(\mathrm{p}=0.011$; Table 1), it may be suggested that the larger ones were old individuals. However, a corresponding trend was not found in females.

Many factors, for example the number of nestlings and their age, the amount and quality of food available and the travel costs between foraging area and the nest, may affect feeding frequencies. The present study suggests that also the physical condition of the parents, also reflected by a role separation of the sexes, may influence the feeding rates of nestlings in Fieldfares breeding in subalpine birch forests.

\section{SAMMENDRAG}

\section{Kjønnsforskjell hos gråtrost i mating av reirunger relatert til foreldrenes størrelse, fysiske kondisjon og reirforsvar}

Som en del av en unders $\emptyset$ kelse av fuglesamfunnet i en fjellbjørkeskog i Budal, Midtre Gauldal kommune i Sør-Trøndelag, ble fôringsfrekvensen av én uke gamle reirunger hos 12 gråtrostpar registrert i årene 1996-1998. Gråtrost-hunnen bygger reiret alene, ruger eggene og er også alene om å varme ungene den første tiden. Dette går trolig på bekostning av hennes vekt og fysiske kondisjon. Som antatt var fôringsfrekvensen (antall fôringsbesøk per time) lavere for hunner enn for hanner. I perioden da reiret ble bygd og eggene lagt, var det ingen forskjell mellom kjønnene i fysisk kondisjon (synlig fett i brystgropen, eller forholdet kroppsvekt/ vingelengde). Etter klekkingen hadde hunnene avtatt $\mathrm{i}$ vekt og var i dårligere kondisjon enn hannene. Også i forsvar av reirungene var det en tilsvarende endring; ingen forskjell i forsvaret før og etter klekking hos hunnene, mens hannene forsvarte reiret mer intenst etter enn før klekkingen. Store hanner (basert på vingelengde) matet ungene oftere enn mindre hanner. 


\section{REFERENCES}

Biermann, G.C. \& Sealy, S.G. 1982. Parental feeding of nestling Yellow Warblers in relation to brood size and prey availability. - Auk 99: 332-341.

Carlson, A. \& Moreno, J. 1986. Foraging behaviour and parental care in the Fieldfare. - Ardea 74: 79-90.

Hogstad, O. 1991. Nest defence in Fieldfares Turdus pilaris towards a human intruder. - Fauna norv. Ser. C, Cinclus 14: 83-87.

Hogstad, O. 1993. Nest defence and physical condition in Fieldfare Turdus pilaris. - J. Orn. 134: 25-33.

Hogstad, O. in press. Sexual differences in nest defence in Fieldfares related to their size and physical condition. - Ibis.

Johnson, E.J. \& Best, L.B. 1982. Factors affecting feeding and brooding of Grey Catbird nestlings. - Auk 99: 148-156.

Meilvang, D., Moksnes, A. \& Røskaft, E. 1997. Nest predation, nesting characteristics and nest defence behaviour of Fieldfares and Redwings. - J. Avian. Biol. 28: 331-337.

Otto, C. 1979. Environmental factors affecting egg weight within and between colonies of Fieldfares Turdus pilaris. - Ornis Scand. 10: 111-116.

Pinkowski, B.C. 1978. Feeding of nestlings and fledgling Eastern Bluebirds. - Wilson Bull. 90: 84-98.

Ricklefs, R.E. \& Hussel, D.J.T. 1984. Changes in adult mass associated with the nestling cycle in the European Starling. - Ornis Scand. 15: 155-161.

Svensson, L. 1992. Identification Guide to European Passerines. Svensson, Stockholm.

Wiklund, C.G. 1983. Social organization and breeding biology of the Fieldfare Turdus pilaris. Ph-D-thesis, Göteborg, Sweden.

Wittenberger, J.F. 1982. Factors affecting how male and female Bobolinks apportion parental investments. - Condor 84: 22-39.

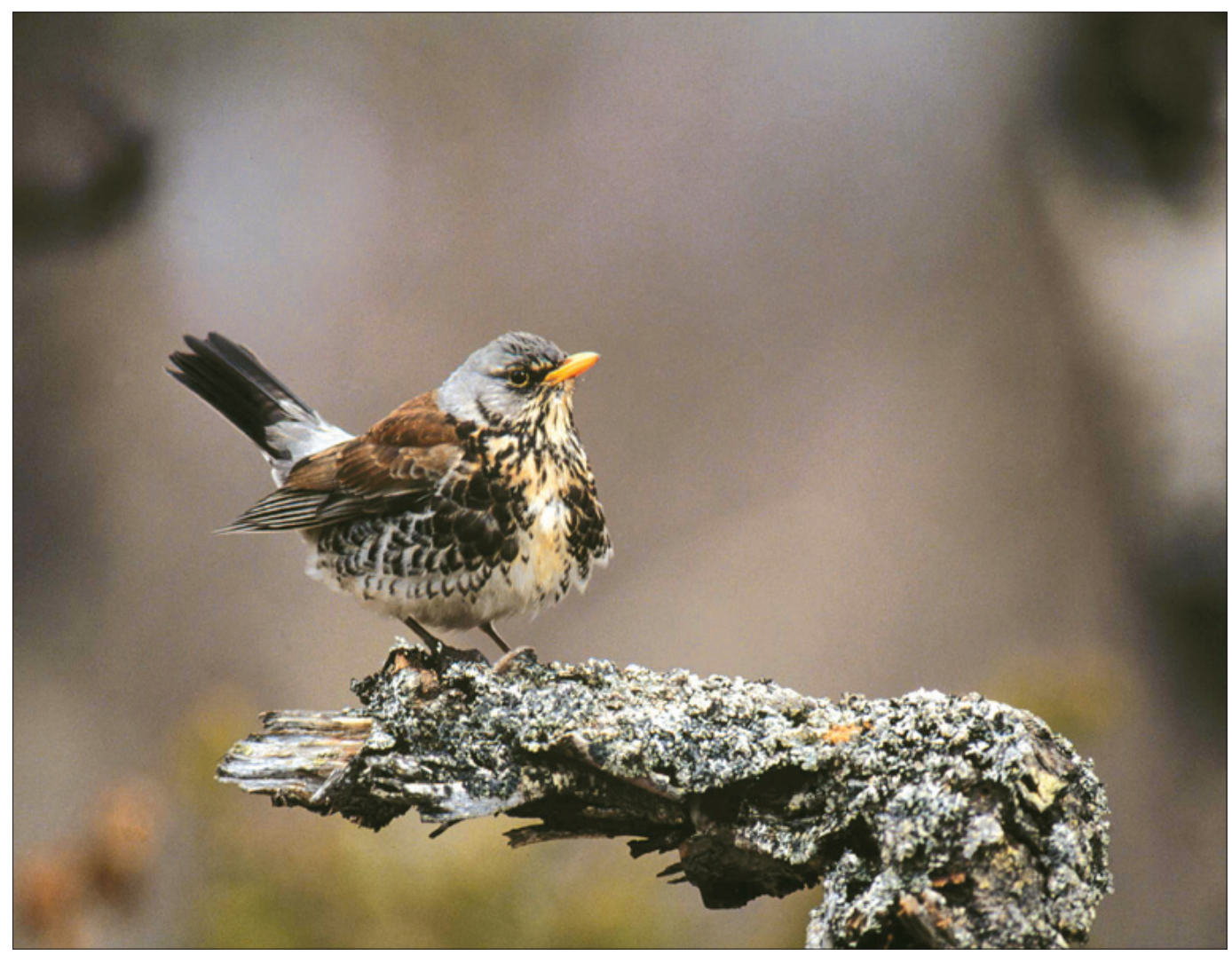

Fieldfare (Turdus pilaris). Photo: Erlend Haarberg. 